Department of Morphology (Prof. K. KURosumI), Institute of Endocrinology,

Gunma University, Maebashi, Japan

\title{
The Correlative Light and Electron Microscopy of the Islets of Langerhans in Some Lower Vertebrates*
}

\author{
Nakazo Watari, ${ }^{* *}$ Noboru Tsukagoshi and Yoshiharu Honma*** \\ （渡 仲三，塚越 昇，本間義治）
}

\section{Received October 13, 1969}

A number of papers on the fine structure of the pancreatic islets in various kinds of vertebrates including the human (THIERY and BADER, 1966) have accumulated (Herman, Sato and Fitzgerald, 1964; Sato, Herman and Fitzgerald, 1966). However, still some problems have remained such as the extrusion mode of the islet cell granules especially of B-cells, which was postulated by some investigators to be diacrine (Fujita and Matsuno, 1967; Koнama, 1968) or Kurosumi's (1961) Type V, whereas by others it is thought to be eruptocrine (LACY, 1962; BJöRKMAN et al., 1963; Williams and Ensinck, 1966) or a Type IV mechanism (KuRosumi, 1961).

Studies of the islet cells in some animals using alternate thick and thin sections in correlative light and electron microscopy were made by several investigators (LACY, 1957a; Esterhuizen and Lever, 1961; LeVer, Jeacock and Young, 1961; Herman, Sato and FitzGerald, 1964; Sato, Herman and Fitzgerald, 1966). With this technique it is possible to identify each cell type as seen by light and electron microscopy, since the differences in the ultrastructure of islet cells correspond to those in the tinctorial characteristics in light microscopic preparations. As far as the authors are aware little is known in this respect in cold-blooded vertebrates, fishes in paticular (FALKMER and Olsson, 1962; Bencosme et al., 1965).

The present paper aims to describe some new findings obtained in the pancreatic islets of the snake and bony fish using the technique of correlative light and electron microscopy.

\section{Materials and Methods}

The splenic portion of the pancreas from the adult snake (Elaphe climacophora) collected from spring to autumnal seasons was fixed either in a 1\% osmic acid solution buffered at $\mathrm{pH} 7.4$ with veronal-acetate and made isotonic with $0.03 \mathrm{mg} / \mathrm{ml}$ sucrose (CAULFIELD, 1957), or in a mixture of $2.5 \%$ glutaraldehyde and $2 \%$ osmic acid adjusted at $\mathrm{pH} 7.4$ with the same amount of sucrose. Early in June, 1968, the principal islet of Langerhans from an adult yellow-tail (Seriola quinqueradiata), $60 \mathrm{~cm}$ in long and kept in an aquarium, was also fixed in a $1 \%$ veronal-acetate buffered osmic acid. Dehydration was performed through a series of ascending concentrations of alcohol solutions. The tissue samples were embedded in Epon 812 (LuFt, 1961).

* This paper is dedicated to Prof. Toshio Ito, Gunma University School of Medicine, in memory of his retirement.

** Present Address: The First Department of Anatomy, Nagoya City University Medical School, Nagoya, Japan.

*** Department of Biology, Niigata University School of Science, Niigata, Japan. 
Thin sections for electron microscopy and thick sections $(2 \mu)$ for light microscopy were cut alternately wtih a Porter-Blum ultramicrotome MT-2.

The thin sections were stained with uranyl acetate (WATson, 1958) followed by lead citrate (REYNOLDS, 1957) in a nitrogen chamber and observed with a Hitachi HU$11 D$ electron microscope.

The thick sections were stained with a further modification of MUNGER's (1961) modified aldehyde thionine-hematoxylin-phloxin B staining of Gomori (1941). Photographs of the stained thick sections taken with a Zeiss ultraphot II were compared with the electron micrographs taken from the adjacent thin section.

\section{A. Light microscopy}

\section{Observations}

Light microscopy of the pancreatic islets of the snake, Elaphe quadrivirgata, reported by Iто, WATARI and YАмАмото (1960) indicated a 1:1 ratio of A and B cell population. In the present observation, however, A-cells with red-stained granules in the periphery of the islet are relatively few in number, while B-cells with blue-stained granules predominate in number and are distributed in the central major portion of the islet (Fig. 1).

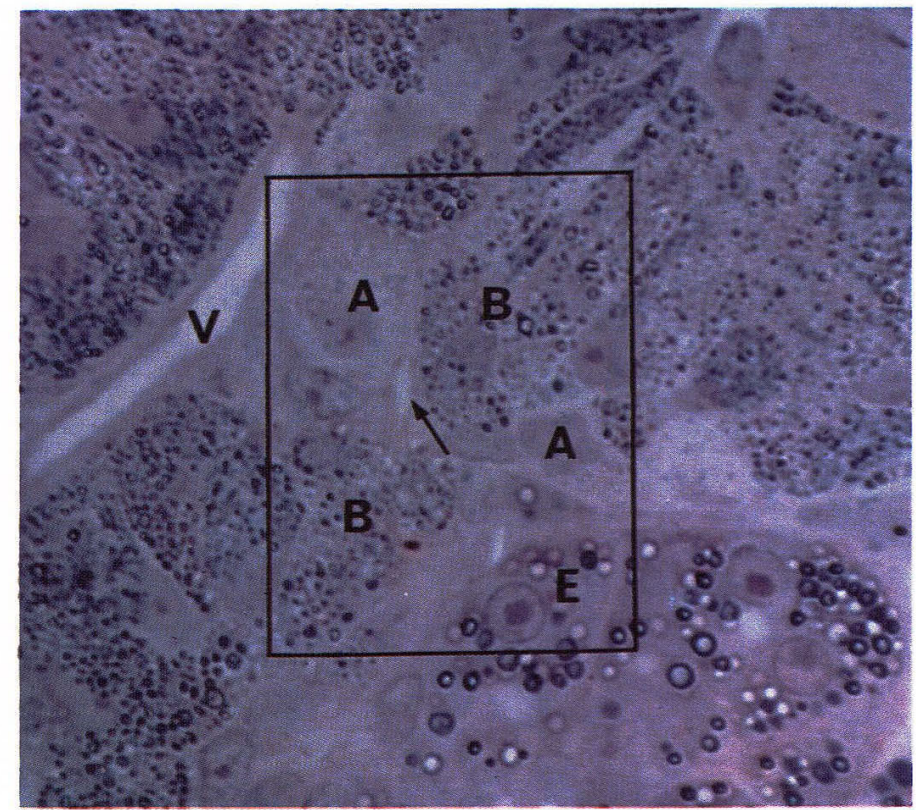

Fig. 1. Snake pancreas. A thick section stained with aldehyde thioninehematoxylin-phloxin B. The rectangular area corresponds to the electron micrograph shown in Figure 2. The A-cells $(A)$ are stained redish; the B-cells $(B)$ blue. The exocrine cells $(E)$ contain large blue-stained zymogen granules. $V$ blood capillary. The arrow indicates a ductule within the islet. $\times 900$

The principal islet or Brockman body in the yellow-tail is found in the retroperitoneal space apart from the exocrine pancreas. This islet tissue is surrounded by 


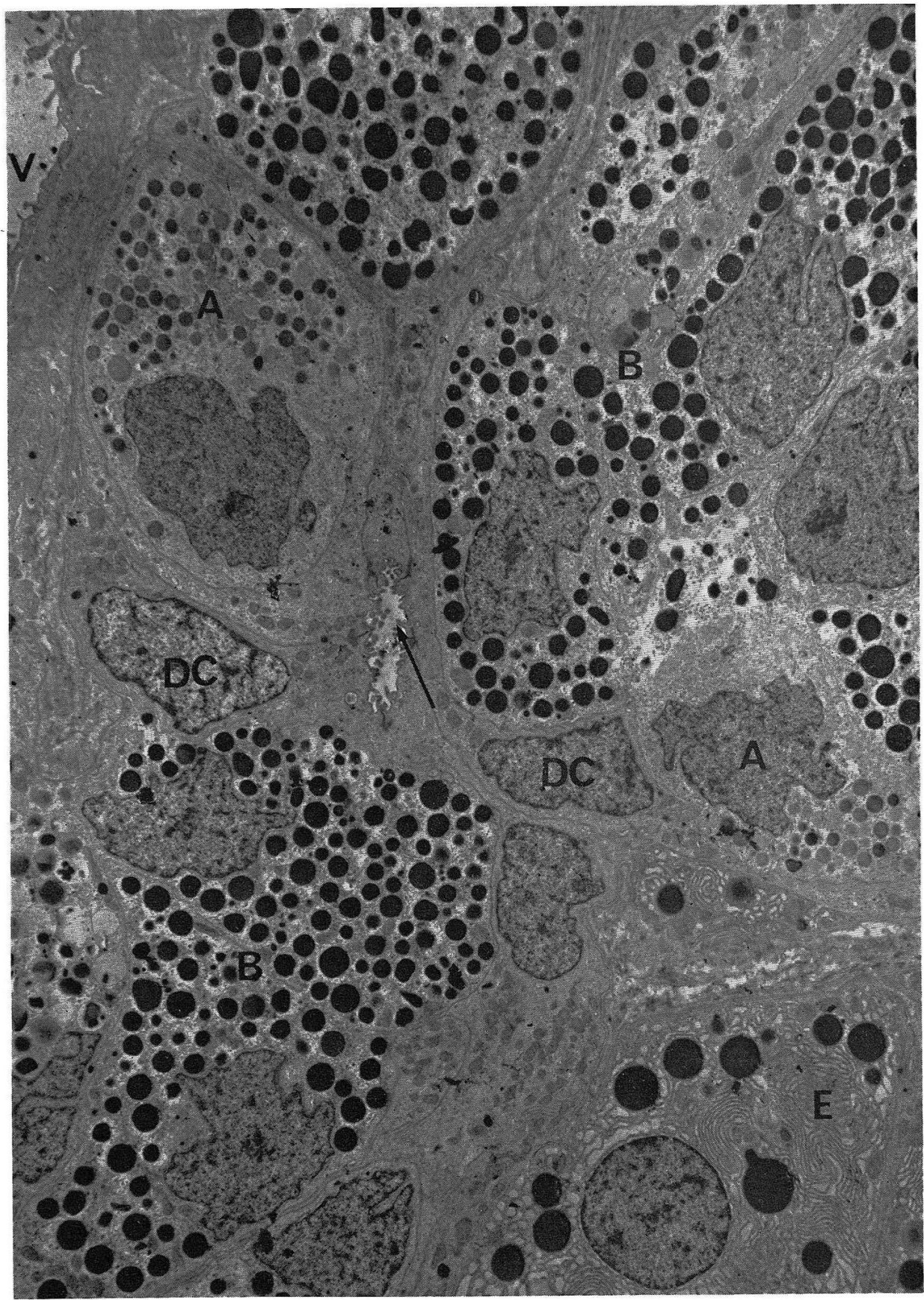

Fig. 2. Snake pancreas. Electron micrograph of the thin section adjacent to the thick section of Figure 1 demonstrating the fine structure within the rectangular area of Figure 1 . $A$ A-cells, $B$ Bcells, $D C$ ductular cells surrounding the narrow ductular lumen (arrow). $V$ blood capillary. $E$ exocrine cells. Fixed with osmic acid alone. $\times 3,000$ 
a fibrous capsule which extends into the islet to separate it into lobules. The islet cells are divided into four types. The first type is A-cell containing a few red-stained secretory granules (Fig. 6). The A-cells are few in number. The second is $\mathrm{B}_{1}$-cell containing dark blue-stained granules (Fig. 6). These cells are relatively few in number and are located near the blood capillaries. The third, the $\mathrm{B}_{2}$-cell, contains light blue-stained granules and occupies a major part of the islet (Fig. 6). The fourth is the C-cell and is characterized by its clear cytoplasm without any secretory granules discernible by light microscopy. This type of ccll is distributed usually among $\mathrm{B}_{2}$-cells and is slightly more numerous than the A-cell (Fig. 6).

\section{B. Electron microscopy}

1. Snake

Under the electron microscope, A-cells of the snake pancreatic islets have an irregularly shaped nucleus and contain two kinds of secretory granules within the same

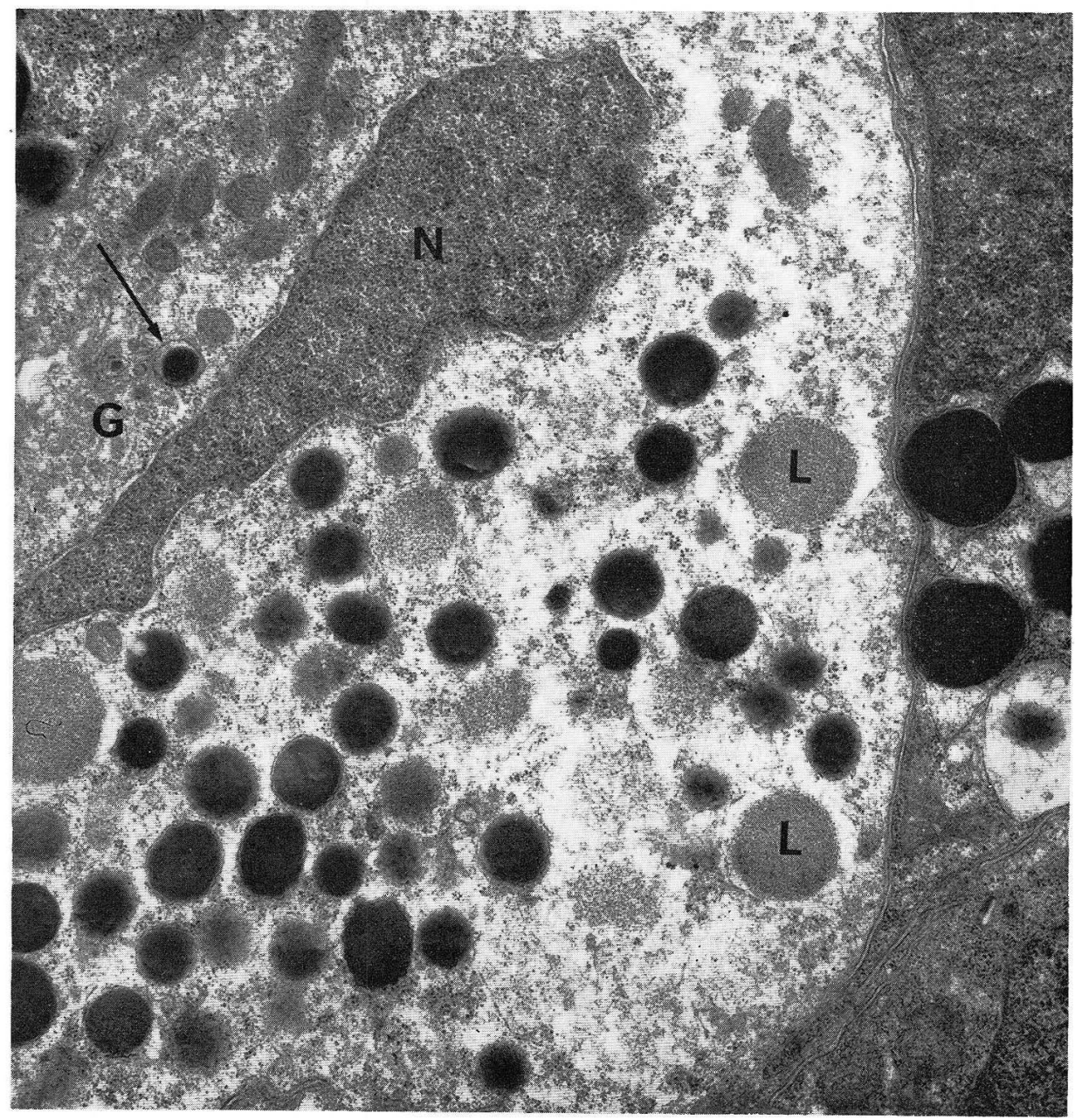

Fig. 3. 
cell, one of which comprises electron dense spherical granules $(300-600 \mathrm{~m} \mu)$ and the other larger and less dense spherical granules $(800 \mathrm{~m} \mu)$ partially encircled by a limiting membrane (Fig. 3). This cell type is clearly correlated to the A-cell with red-stained

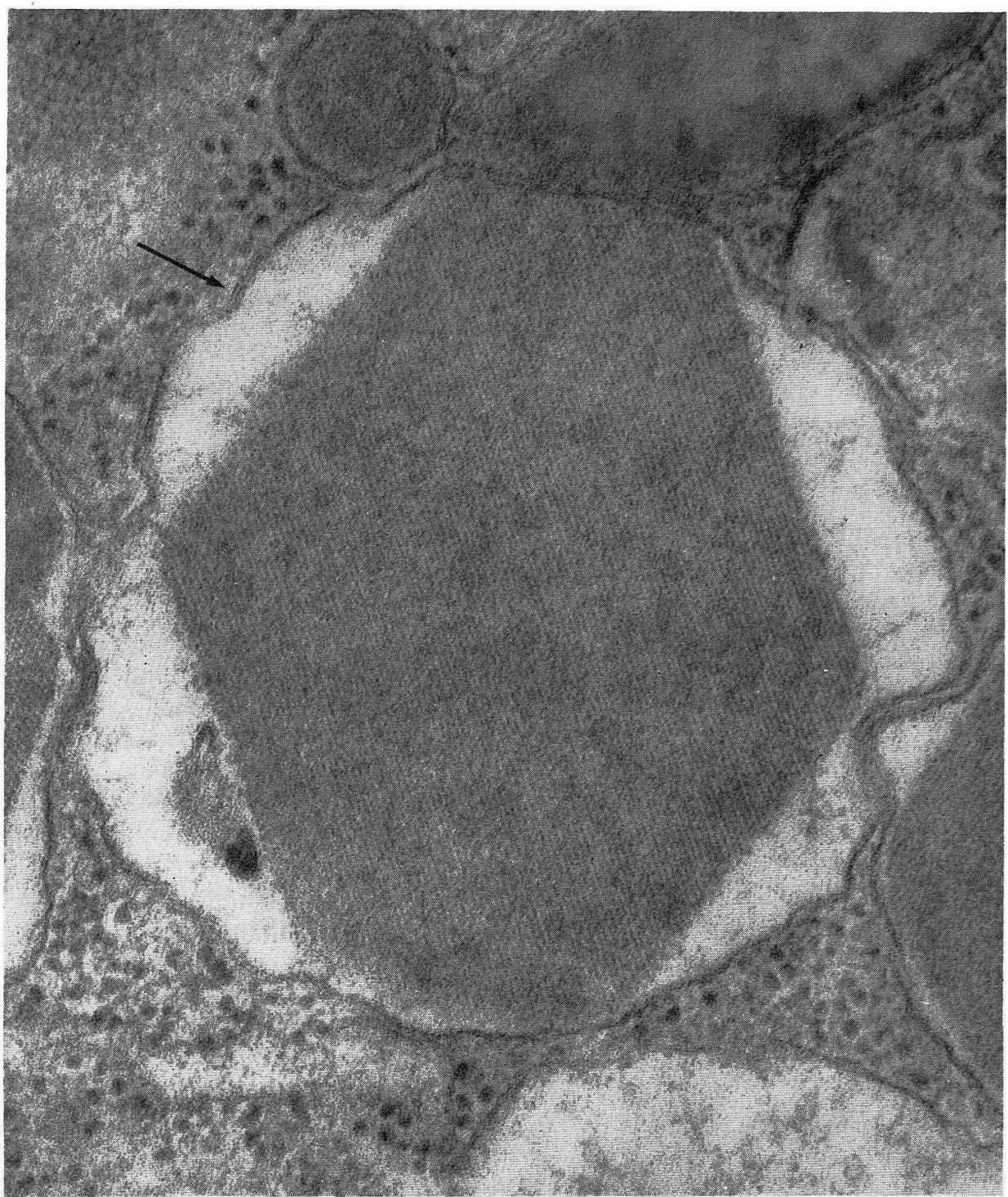

Fig. 4. Hexagonal B-cell granule surrounded by a unit membrane (arrow). Lamellar structure with a periodicity of about $90 \AA$ is shown. Snake pancreatic islet fixed with a mixture of glutaraldehyde and osmic acid. $\times 81,000$

Fig. 3. A-cell occurring in the snakc pancrcas. There are two kinds of secretory granules, one of which is small and electron dense, whereas the other large and less dense $(L)$. In the Golgi apparatus $(G)$ some immature secretory granules are observed (arrow). $N$ nucleus. Fixed with a mixture of glutaraldehyde and osmic acid. $\times 16,000$ 
granules as seen by light microscopy (compare Figure 1 with Figure 2).

B-cells with an irregular nucleus contain variably shaped secretory granules measuring about $800-1,200 \mathrm{~m} \mu$ in diameter (Fig. 2). One type of B-cell contains electron dense spherical granules (Fig. 2). A second type shows crystalline granules rectangular, triangular or irregular in shape (Fig. 2, 16d), the most characteristic shape being hexagonal (Fig. 4,5). These crystalline granules are usually surrounded by a smooth limiting membrane which corresponds to the unit membrane as in other secretory granules (Fig. 4). The crystalline granules show a lamellar structure with a periodicity of about $90 \AA$ (Fig. 4,5). Some subunits are recognized as dotted lines arranged in parallel (Fig. 5). In some granules a single limiting sac contains two or more crystals. Some hexagonal granules show double structures, their periphery being composed of a more electron dense rim and the interior showing a less dense crystalline structure (Fig. 5).

These islet cells are clearly identified with the B-cells by light microscopy of the adjacent thick section (compare Figure 1 with Figure 2).

A narrow excretory ductule surrounded by several elongated cells is observed between the islet cells as already reported by ITo, WATARI and YAMAMOTO (1960) using the light microscope (Fig. 1, 2).

\section{Yellow-tail:}

The electron microscopy of the pancreatic islets of the yellow-tail demonstrated that the A-cells with a dark, irregularly shaped nucleus contain dense spherical granules measuring about $200-300 \mathrm{~m} \mu$ in diameter (Fig. 8, $16 \mathrm{c}$ ). Some A-cells contain a few peculiar inclusion bodies which are limited by a single membrane and show filamentous structures (Fig. 8).

$\mathrm{B}_{1}$-cells contain crystalline granules measuring $300-600 \mathrm{~m} \mu$ in diameter (Fig. 9, 10, $15,16 \mathrm{a})$. The granules were very variable in shape, some showing a hexagonal shape like the B-cell granules of the snake (Fig. 10, 15, 16a). In some cases a single limiting sac contains two or more crystalline granules as in the B-cells of the snake (Fig. 10, 16a). Some secretory granules are packed with needle-like crystals, but others contain amorphous masses together with hexagonal crystals (Fig. 10).

$\mathrm{B}_{2}$-cells having a round nucleus contain secretory granules $(200-600 \mathrm{~m} \mu)$ of lower density, which are amorphous and surrounded by a circular limiting membrane (Fig. $11,16 \mathrm{~b}$ ). The $\mathrm{B}_{2}$-cells possess a well-developed Golgi apparatus and rough endoplasmic reticulum (Fig. 11), some of the cisternae of which are continuous with the outer nuclear membrane (Fig. 11). Some $\mathrm{B}_{2}$-granules contain needle-like crystals embedded in a less dense amorphous matrix (Fig. 11, 16b). In the Golgi apparatus of the $\mathrm{B}_{2}$-cell sometimes occur small immature secretory granules whose electron density is lower than the mature granules (Fig. 11). The C-cells, which are unstainable and therefore appear clear under the light microscope, are subdivided into two types by electron microscopy: one $\left(\mathrm{C}_{1}\right.$-cell) is located usually between the $\mathrm{B}_{2}$-cells and characterized by a number of vacuoles $(300-600 \mathrm{~m} \mu$ in diameter) whose size roughly corresponds to that of $\mathrm{B}_{1}$-cell granules. Some of the vacuoles contain filamentous structures resembling those of the $\mathrm{B}_{1}$-cell granules (Fig. 12). Many free ribosomes fill the cytoplasmic matrix among the vacuoles of $\mathrm{C}_{1}$-cells (Fig. 12$)$. The second type of $\mathrm{C}$-cell $\left(\mathrm{C}_{2}\right.$-cell) contains a stuck of the rough endoplasmic reticulum and has no secretory granules (Fig. 13). 
Some cells whose fine structure corresponds to that of the so-called $\mathrm{C}_{2}$-cells contain, when carefully observed with the electron microscope, a few immature granules in the Golgi apparatus, which are similar in appearance to the A-cell granules. This suggests that these cells represent a transitional cell type between the $\mathrm{C}_{2}$ and $\mathrm{A}$ cells (Fig. 13).

A few cells contain simultaneously $B_{1}$ and $B_{2}$ cell granules, suggesting that they are transitional forms between both types. Some other cells also contain along with

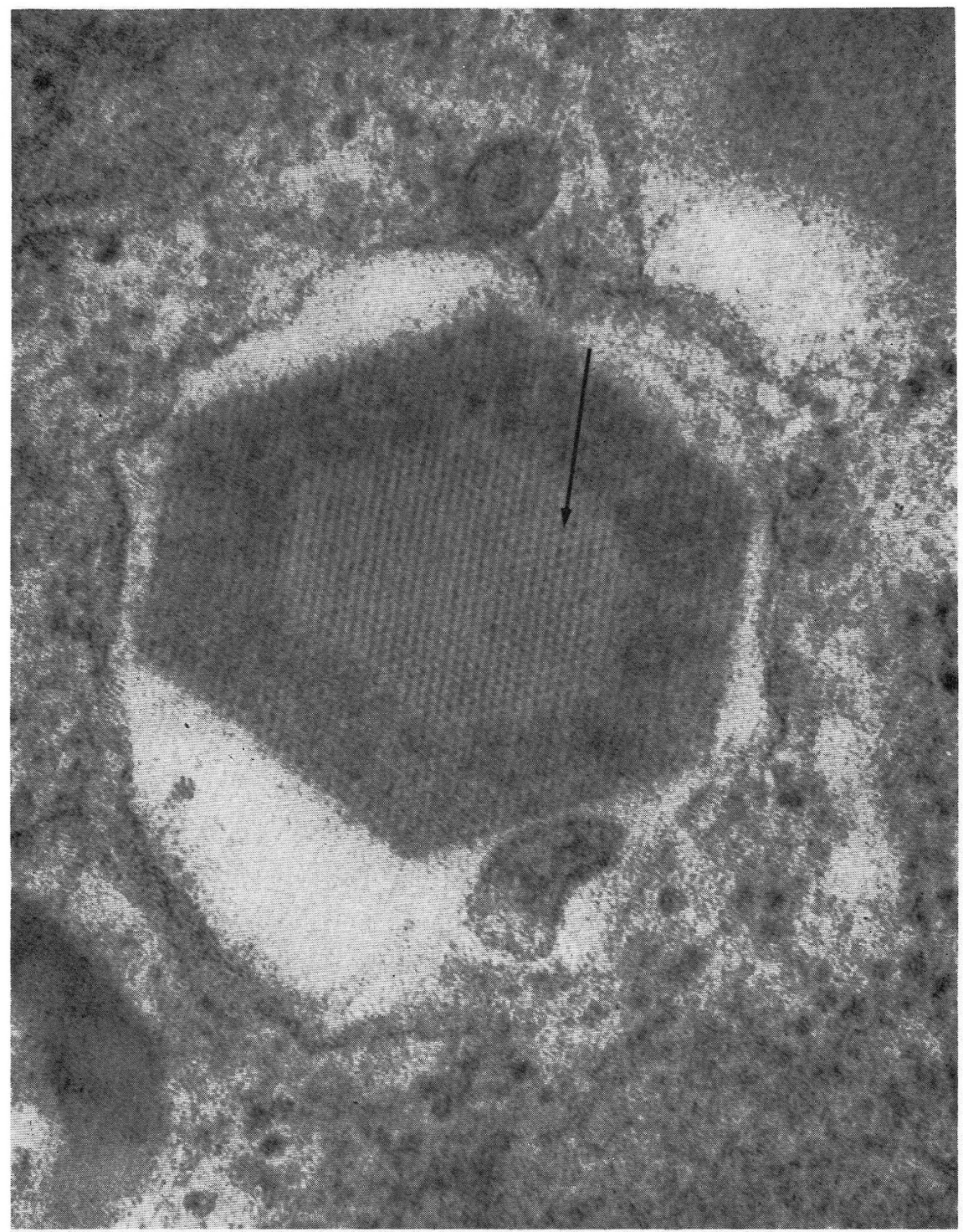

Fig. 5. Hexagonal granule of the snake B-cell fixed with a mixture of glutaraldehyde and osmic acid. The crystalline granule has a double structure composed of an electron dense rim and the less dense core showing dotted lines arranged in parallel (arrow). $\times 68,000$ 
$B_{1}$ and $B_{2}$ ccll granules, a large number of vacuoles resembling the $C_{1}$-cell vacuoles (Fig. 14).

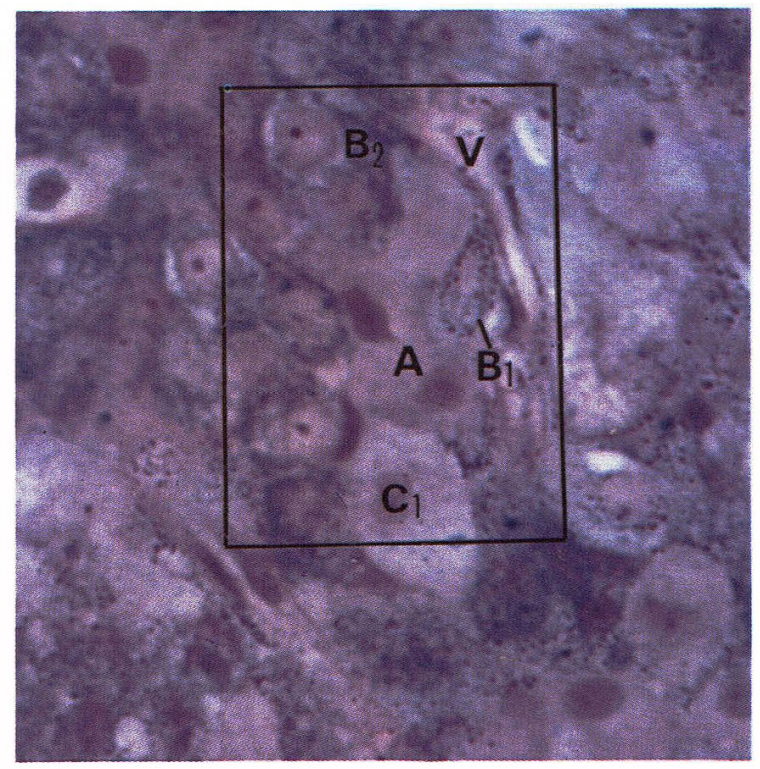

Fig. 6. A thick section from the yellow-tail stained with aldehyde thionine-hematoxylin-phloxin $\mathrm{B}$. The rectangle indicates the area to be compared with the electron micrograph in Figure 7. The A-cells $(A)$ are stained red, $\mathrm{B}_{1}$-cells $\left(B_{1}\right)$ contain blue-tinged granules, $C_{1} C_{1}$-cell without granules. $V$ blood capillary. $\times 1,000$

When one carefully observes along the peripheral portion of the $\mathrm{B}_{1}$-cells facing the blood capillary, he can often find figures which suggest eruptocrine (Type IV) extrusion of secretory granules. It seems likely that the secretory granule moves to the periphery of the cell, the limiting membrane of the granule comes into contact with the plasma membrane, and then a pore opens at the fused portion of the granule membrane and plasma membrane, leading the granular content to the extracellular space. Sometimes hexagonal crystal granules are found in the extracellular space without any deformation, judged to be just after extrusion (arrows in Figure 15).

As recently reported by LeGG (1967) and WATARI (1968a, b), some unmyelinated nerve fibers enter the pancreatic islets of both the snake and yellow-tail fish, and terminate close to the islet cells forming nerve terminals with (Fig. 16b) or without membrane thickening (Fig. 16a, c, d). Some nerve terminals contain only non-cored synaptic vesicles of $500 \AA$ diameter along with some mitochondria (Fig. 16a), whereas others contain, besides these, a few large cored vesicles $(1,000 \AA)$ (Fig. 16c). Further, there are found some terminals showing numerous large cored vesicles and a few small cored vesicles (500 $)$ ) (Fig. 16d). 


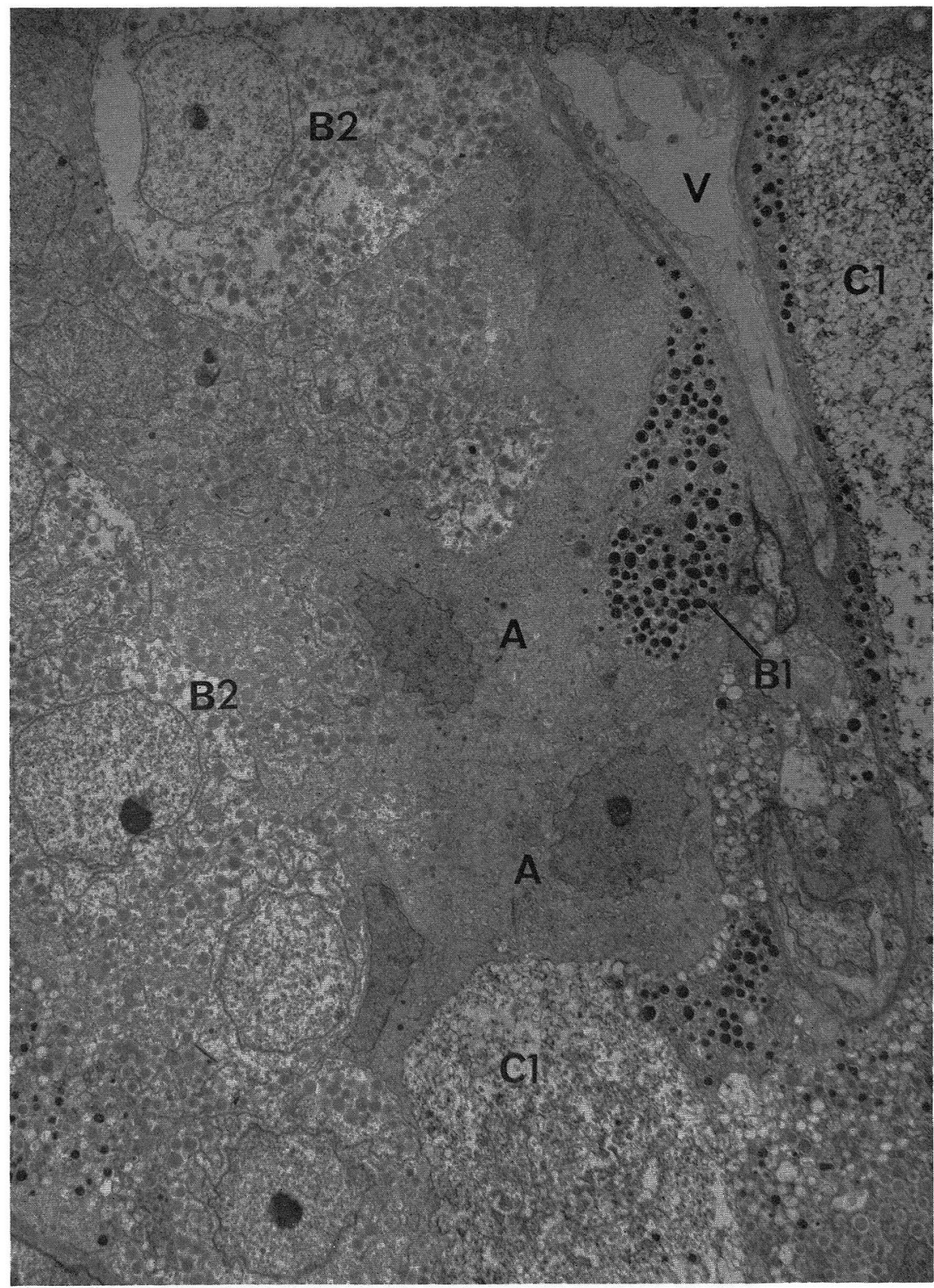

Fig. 7. A thin section adjacent to the rectangular area in Figure 6 . The A-cells $(A)$ show dark irregular-shaped nuclei and dark cytoplasm. The $B_{1}$-cell $\left(B_{1}\right)$ contains electron dense granules and the $\mathrm{B}_{2}$-cells $\left(B_{2}\right)$ less dense ones. The $C_{1}$-cells $\left(C_{1}\right)$ are filled with vacuoles. $V$ blood capillary. $\times 3,500$ 


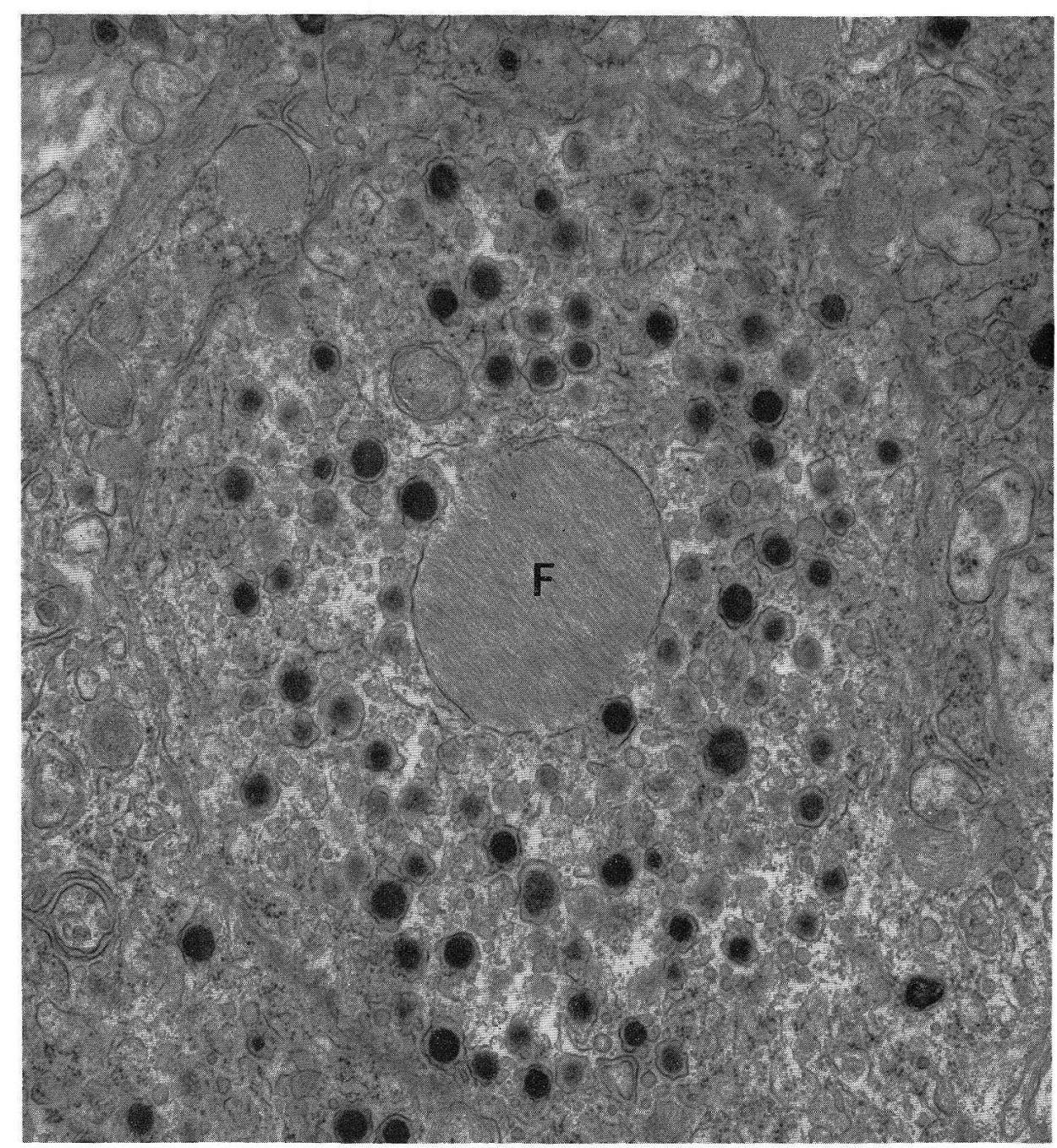

Fig. 8. A-cell in the yellow-tail islet. It contains electron dense small granules and a large inclusion body containing a fine filamentous substance $(F) . \quad \times 24,000$

\section{Discussion}

The shape of the secretory granules of the islet B-cell is mostly characteristic to species. In almost all the vertebrate species, they are crystalline or diamond-shaped except for rodents. However, GREIDER, Howell and LACY (1969) recently found that some B-cell granules of the rat, after isolation by the fractionation method and stained with phosphotangstic acid, showed a crystalline structure with a periodicity of about $50 \AA$. WAtari (unpublished data) also found that some B-cells of the mouse contain a few secretory granules of rod or hexagonal shape. It has been shown that the shape of secretory granules of the B-cell may vary under certain conditions. For example, the bat pancreatic B-cells contain a large number of amorphous secretory granules 


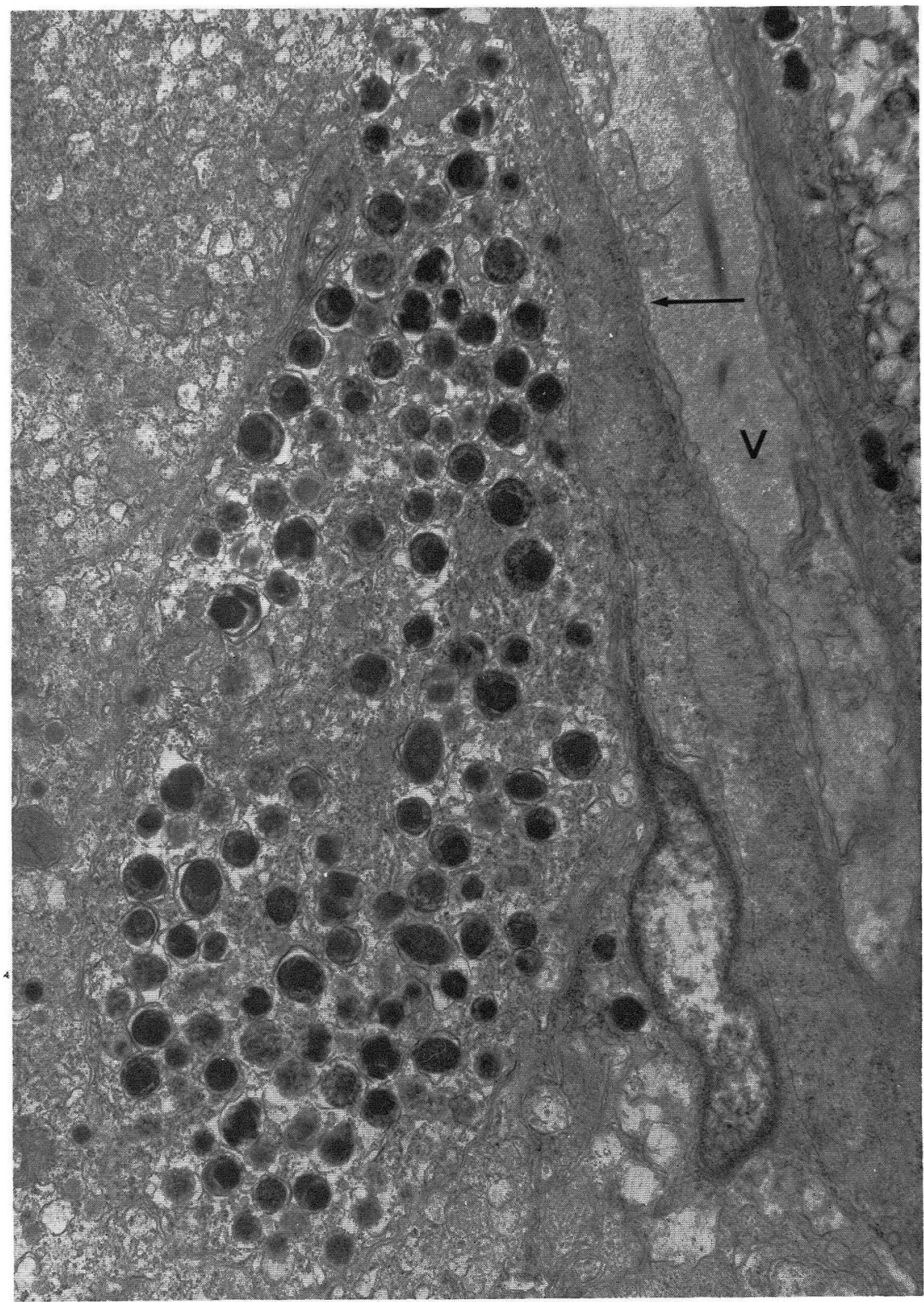

Fig. 9. Higher magnification view of the $\mathrm{B}_{1}$-cell illustrated in Figure 7. The cell contains electron dense secretory granules, some of which are hexagonal in shape. Attenuated portions of the endothelial cell of the blood capillary $(V)$ show fenestration (arrow). $\times 15,000$ 


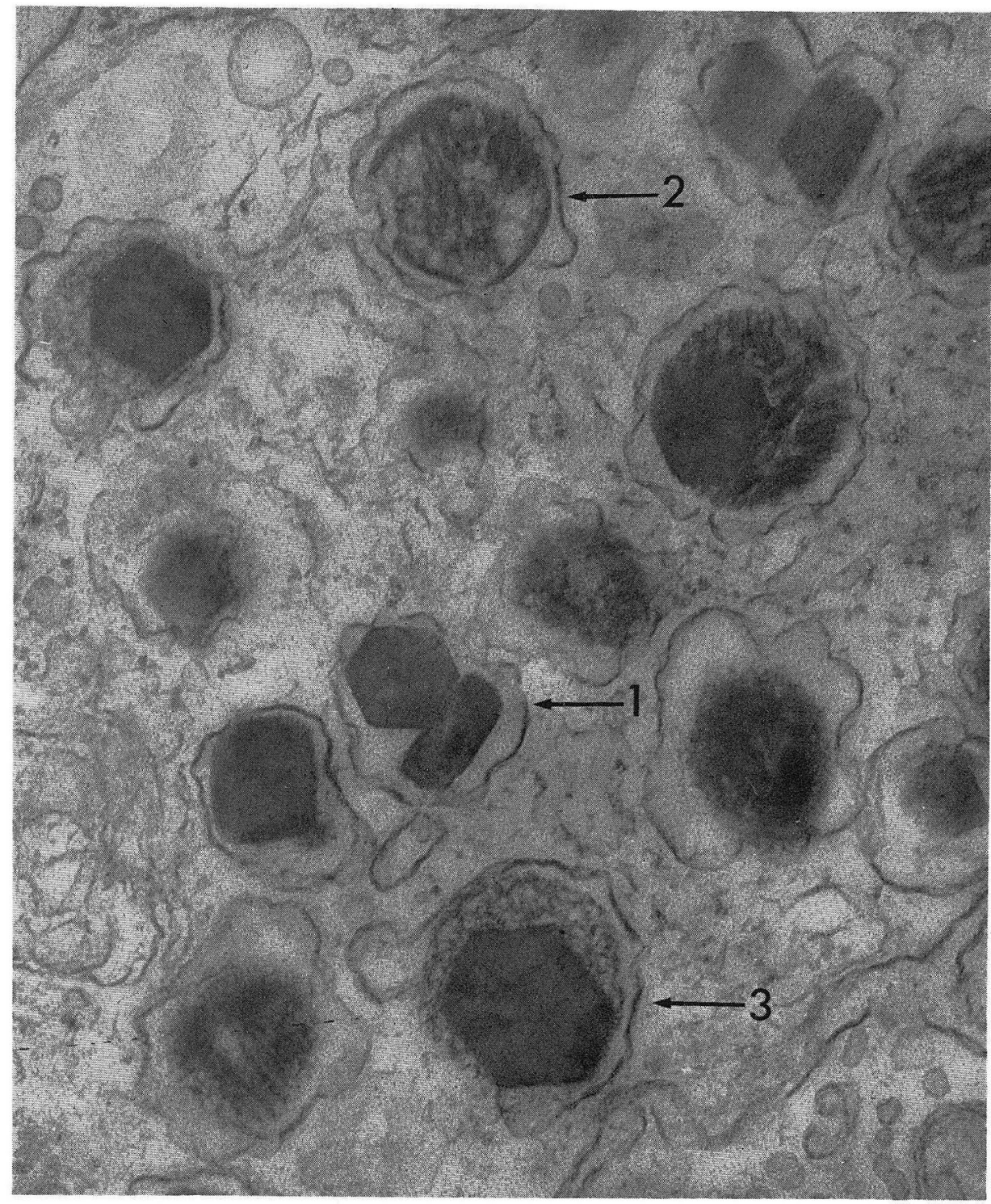

Fig. 10. Part of the $B_{1}$-cell cytoplasm from the pancreatic islet of the yellow-tail. Some of the secretory granules are hexagonal or diamond-shaped (arrow -1) and others contain a packet of needlelike crystals (arrow-2), or amorphous masses along with hexagonal crystals (arrow-3). $\times 64,000$

under normal conditions. But come to show crystalline granules when the animals are hibernating (Watari and Herman, 1965; Watari, 1968b). The crystallization of the B-cell granules is also influenced by fixation chemicals. When fixed with a mixture of glutaraldehyde and osmic acid, most B-cell granules of the snake take a crystalline form (Fig. 4, 5), but after fixation with a plain osmic acid solution most of them appear amorphous (Fig. 2). These facts suggest a possibility that the B-cell granules of every 


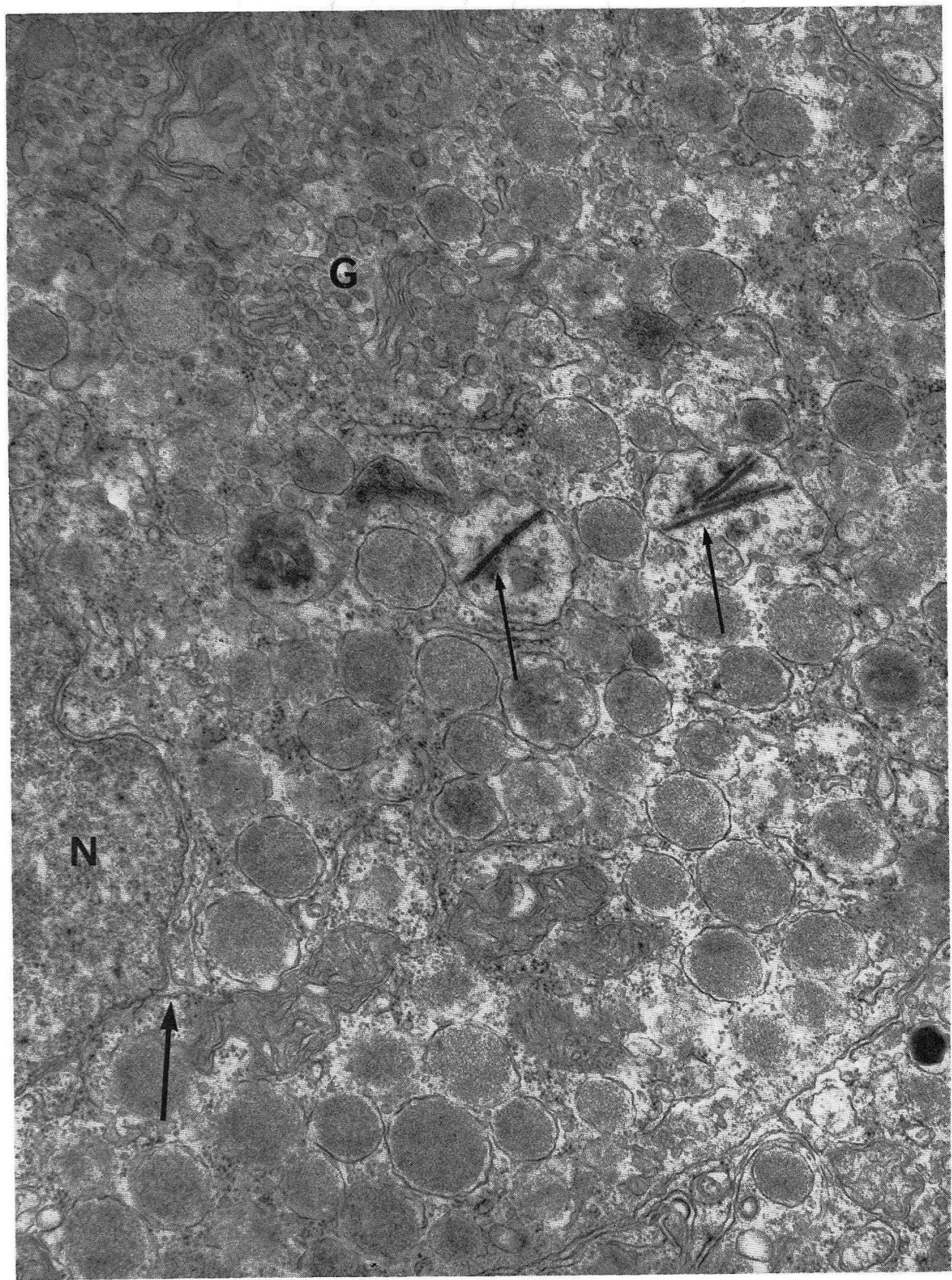

Fig. 11. B -cell with less dense secretory granules from the yellow-tail. Some granules show needlelike crystals (thin arrows). The Golgi apparatus $(G)$ contains less dense immature granules. The rough endoplasmic reticulum is continuous (thick arrow) to the outer membrane of the nucleus $(N)$. 


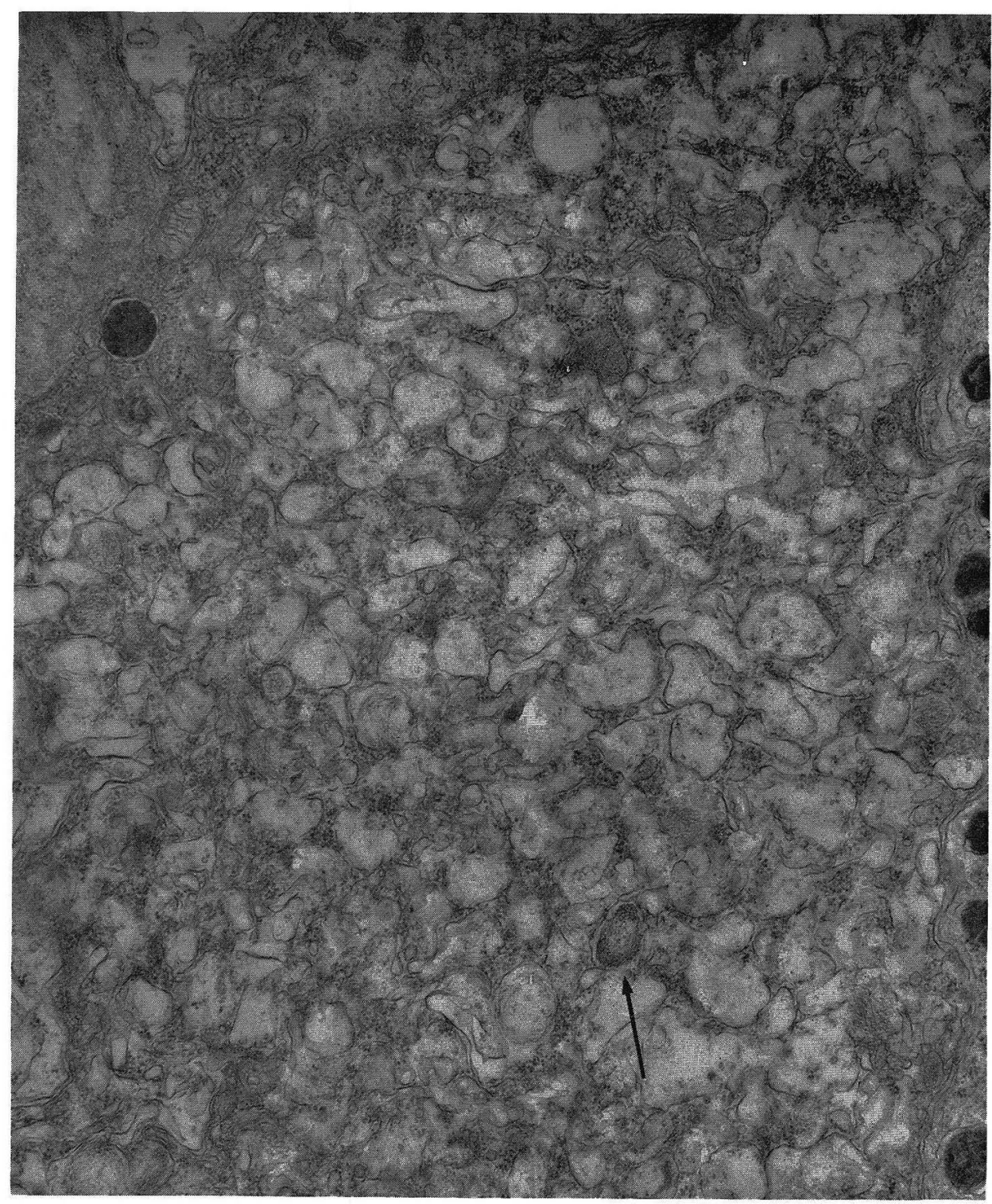

Fig. 12. $\mathrm{C}_{1}$-cell filled with empty vacuoles, some of which contain filamentous substance (arrow). A number of free ribosomes are seen in the cytoplasmic matrix among the vacuoles. Yellow-tail. $\times 23,000$

vertebrate species may appear in crystal forms under certain physiological conditions or when appropriately fixed.

In their recent light and electron microscope study on the pancreatic islets of the grass-snake, Trandaburu and Călugăreanu (1969) found hexagonal granules in the B-cells, but showed no periodic structure within them. The authors, though failing 


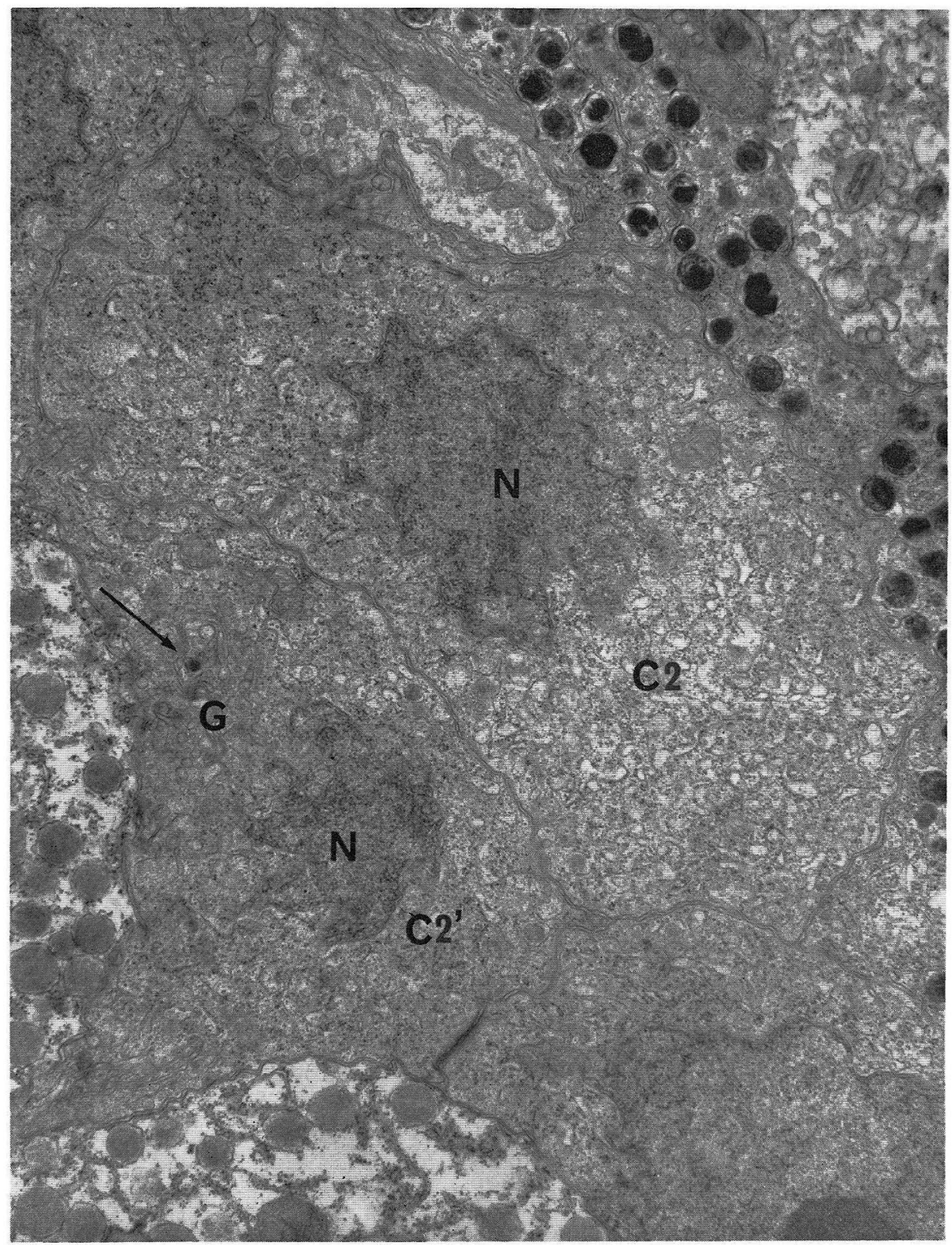

Fig. 13. $C_{2}$-cell $\left(C_{2}\right)$ from the yellow-tail pancreatic islet without any secretory granules. A similar cell $\left(C_{2}{ }^{\prime}\right)$ contains an immature secretory granule within the Golgi apparatus $(G)$, suggesting its possible origin from the A-cell. The cells possess dark cytoplasm containing rough endoplasmic reticulum. $N$ nuclei. $\times 14,000$

to demonstrate this structure in the yellow-tail $\mathrm{B}_{1}$-granules, could show it clearly in the snake B-cells. The variability in this periodic appearance is suggested to depend 


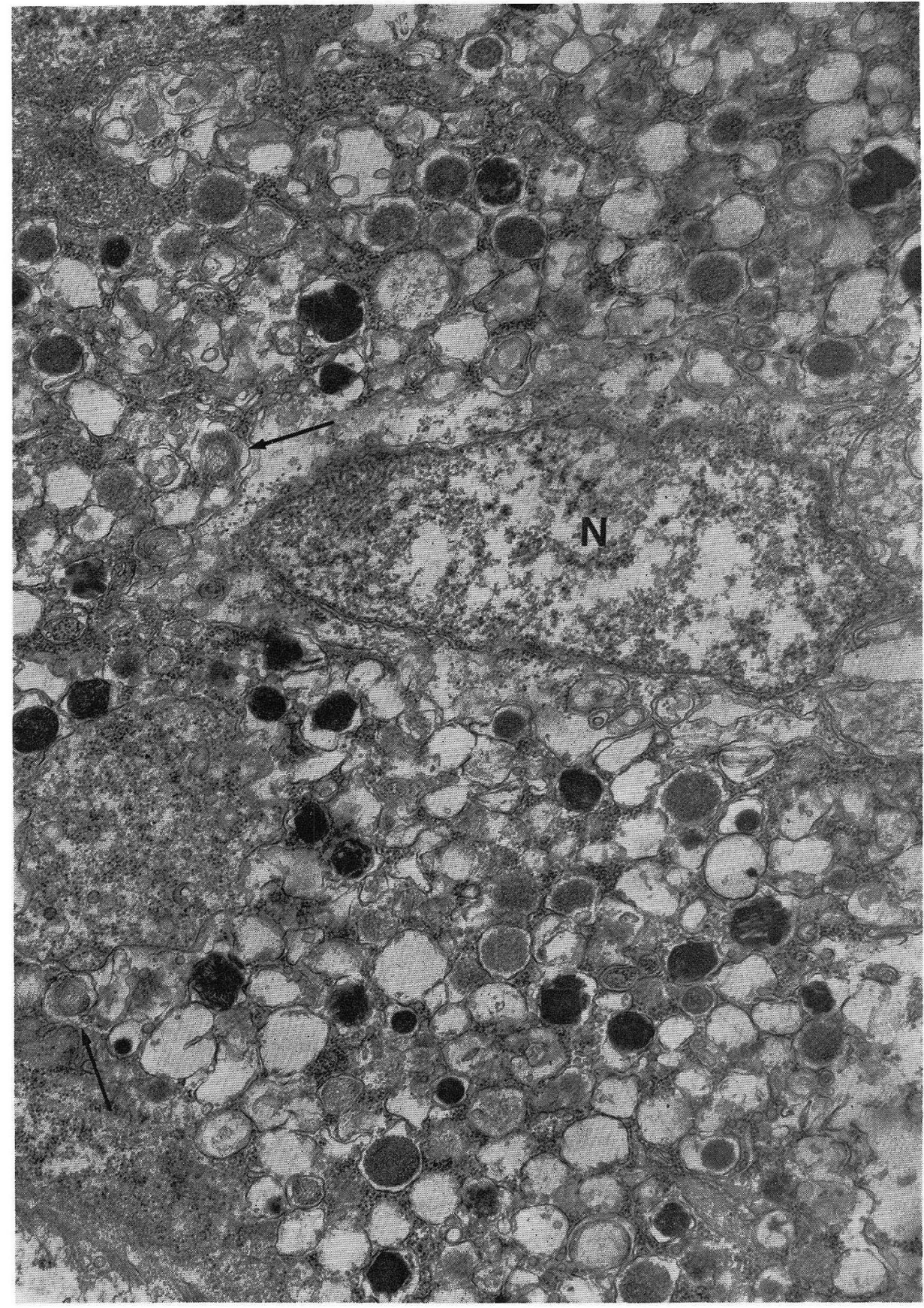

Fig. 14. One of the transitional cell types occurring within the pancreatic islet of the yellow-tail. The cell contains less dense secretory granules ( $\mathrm{B}_{2}$-cell granules), electron dense crystalline granules $\left(\mathrm{B}_{1}\right.$-cell granules) and vacuoles ( $\mathrm{C}_{1}$-cell vacuoles). Arrows indicate the vacuoles containing filamentous substance. $N$ nucleus. $\times 23,000$ 


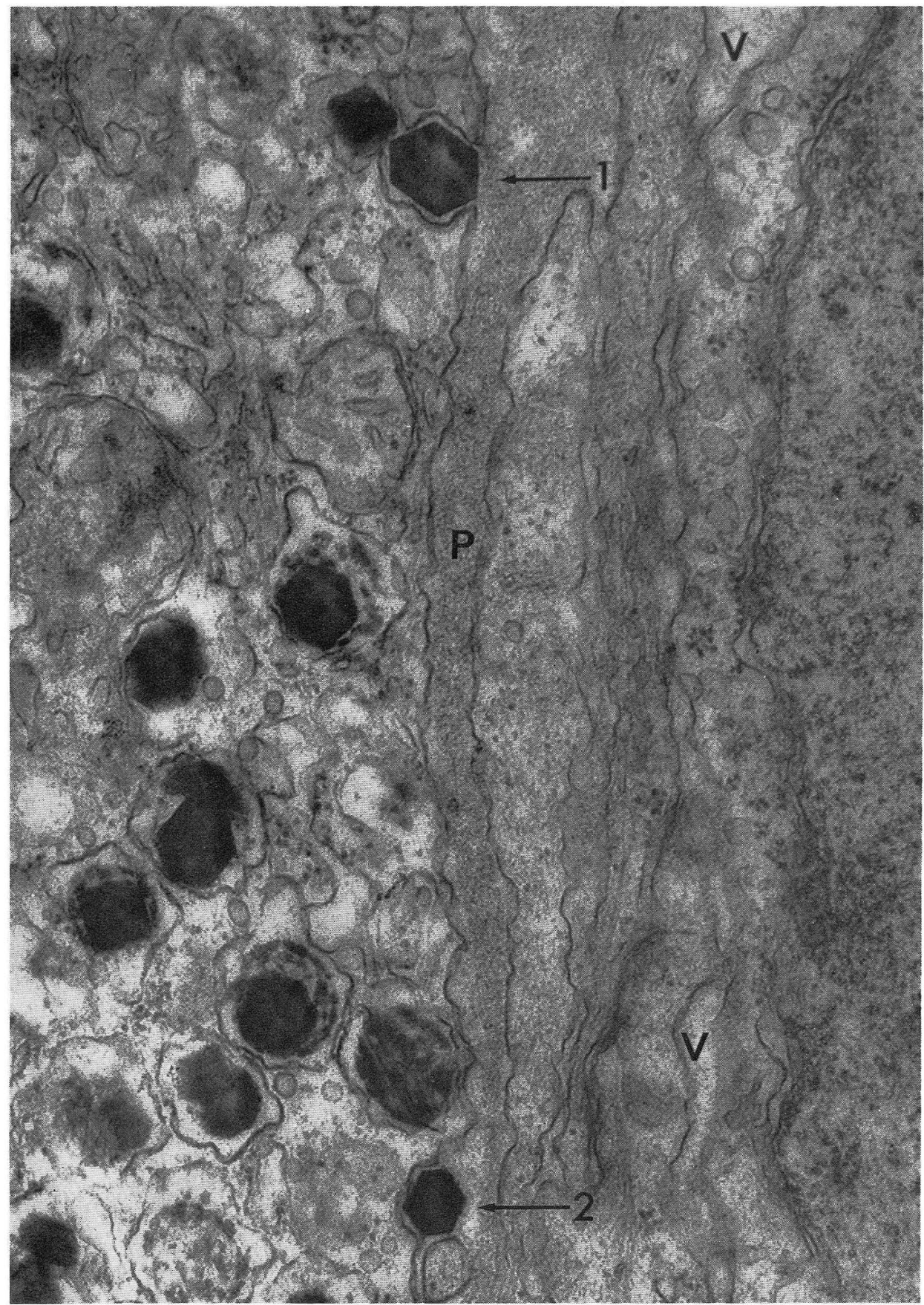

Fig. 15. $B_{1}$-cell facing a blood capillary $(V)$. Arrows show the extrusion of crystalline granules. The limiting membrane of the granule touches the plasma membrane and opens a pore (arrow-1) to extrude its contents into the pericapillary space $(P)$. Arrow-2 indicates the hexagonal granule which is already released to the outside of the cell. $\times 49,000$ 

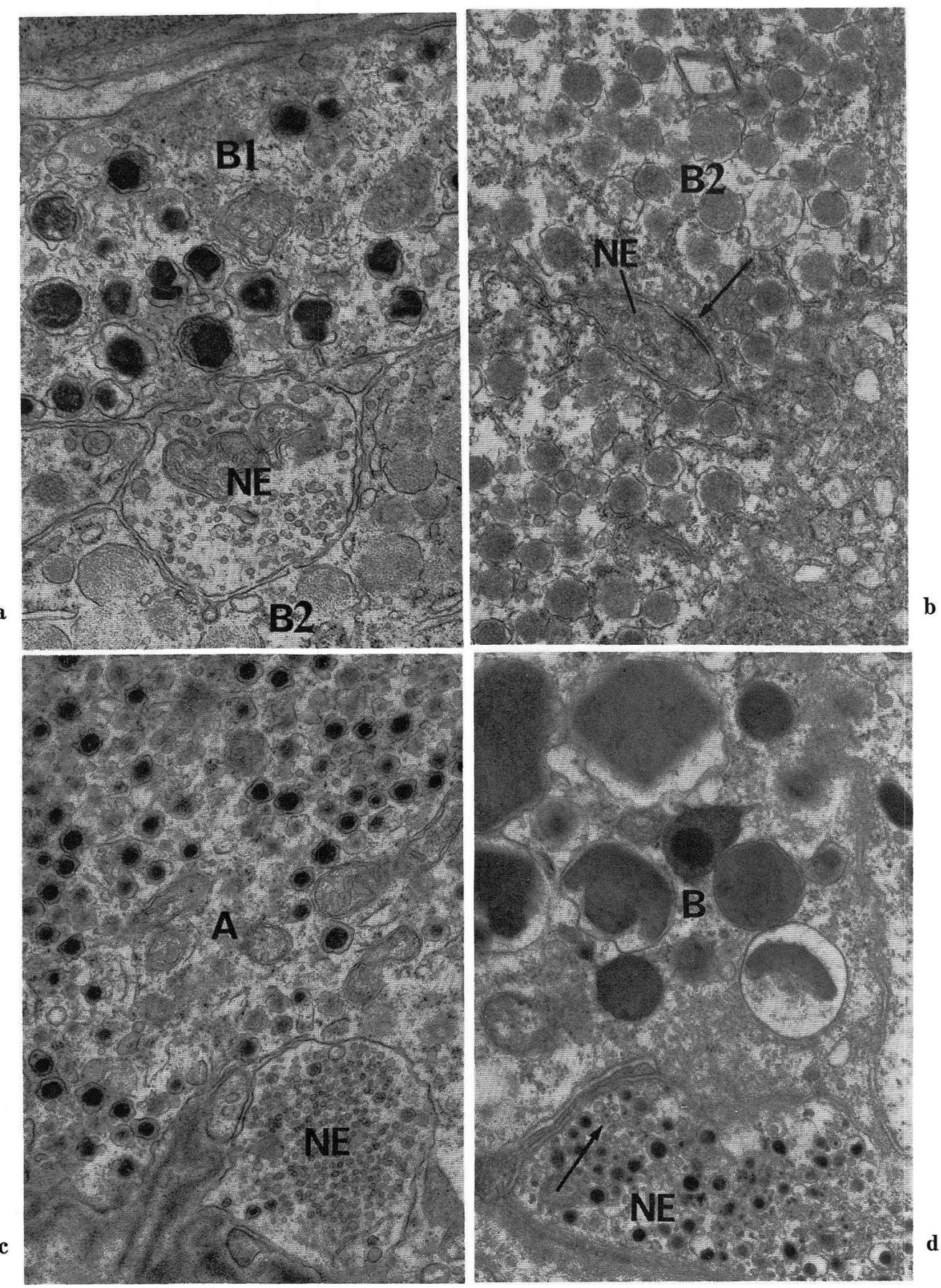

Fig. 16. 
on the difference in the molecular structure of either insulin or its associated protein suggested by LACY (1962).

The $\mathrm{B}_{2}$-cells of the yellow-tail contain less dense amorphous granules resembling the secretory granules of the so-called D-cell of the islets of other species, which have been reported in many papers (see FujITA, 1968). However, these cells can be identified as relatively young B-cells, because their secretory granules were stained light blue with aldehyde thionine which always stains B-cell granules a bluish tint. The secretory granules of the so-called D-cell are entirely amorphous or ghost-like in shape, but the $\mathrm{B}_{2}$-cell granules of the yellow-tail sometimes contain needle-like structures similar to the crystals of $\mathrm{B}_{1}$-cell granules, suggesting that the granules are composed of insulin or insulin-binding protein. Though some investigators (EPPLE 1966; FuJITA, 1968) postulated that the $\mathrm{D}$-cell is an independent islet cell which may secrete a third islet hormone, we could not find a cell deserving this designation in this experiment.

One of the clear cells of the yellow-tail containing a large number of empty sacs $\left(\mathrm{C}_{1}\right.$-cell $)$ may be identified as degranulated B-cells, because they sometimes contain vacuoles with filamentous structures resembling the $\mathrm{B}_{1}$-cell granules. Transitional cell types between the $\mathrm{B}_{1}, \mathrm{~B}_{2}$ and $\mathrm{C}_{1}$ cells sometimes occur in the yellow-tail islets. It is thus evident that these three cell types represent only functional stages of one cell type. It is also very likely that the $\mathrm{C}_{2}$-cells of the yellow-tail are degranulated A-cells, because transitional cell types between both cells are frequently observed.

The extrusion mechanism of the islet cell granules has been discussed by many investigators. Concerning A-cells, it seems safe to conclude that the granules are released mainly by the eruptocrine or Type IV extrusion mechanism (KuRosumI, 1961) as reported by many investigators (Machino, 1966; Machino, Onoe and Sakuma, 1966; Przybylski, 1967; Gomez-Acebo, Parrilla and R-Candela, 1968). The eruptocrine mechanism is sometimes called emiocytosis which was named by LACY (1962). As for the B-cells a majority of investigators (KонамA, 1968) have proposed diacrine or Type V extrusion mechanism (KurosumI, 1961), although some investigators suggested Type IV extrusion (LACY, 1962; Williams and ENSINCK, 1966). However, they did not demonstrate the evidence for such extrusion mechanisms, only showing a speculative drawing.

The present study revealed for the first time the Type IV extrusion of the granules of B-cells without any dissolution of their crystalline structures in the islets of the yellow-tail.

Physiologists have postulated two phases in insulin secretion (TARUI, 1966). One is called the basal secretion which maintains normal blood sugar levels, and the second is called the extra secretion which controls the blood sugar level during the emergency increase. If this view is accepted, it may be possible that insulin-containing granules of the B-cell are released in two different ways (diacrine and eruptocrine), although it is not clear that which one is matched to the basal secretion or to the extra secretion.

Fig. $16(\mathbf{a}, \mathbf{b}, \mathbf{c}, \mathbf{d}) . \quad \times 17,000$. Four different types of nerve endings $(N E)$ from the snake $(\mathbf{d})$ and yellow-tail $(\mathbf{a}, \mathbf{b}, \mathbf{c})$. a. Nerve ending found between the $\mathrm{B}_{1}\left(B_{1}\right)$ and $\mathrm{B}_{2}\left(B_{2}\right)$ cells containing only synaptic vesicles (about $500 \AA$ ). b. Nerve ending containing only synaptic vesicles. The arrow indicates membrane thickening. $B_{2} \mathrm{~B}_{2}$-cells. c. Nerve ending containing a large number of synaptic vesicles with some large cored vesicles (about 1,000 ). $A$ A-cell. d. Nerve ending containing a few small cored vesicles $(500 \AA$, arrow) and large cored vesicles. $B$ B-cell. The last specimen (d) was fixed with a mixture of glutaraldehyde and osmic acid. 


\section{Summary}

Observations were made on the pancreatic islets of the snake, Elaphe climacophora, and a teleost, yellow-tail or Seriola quinqueradiata, using alternate thick and thin sections for light and electron microscopy.

Under the light microscope, the snake islets contain A-cells with red-stained secretory granules and B-cells with blue-stained granules. The islets of the yellow-tail consist of A-cells with red granules, $\mathrm{B}_{1}$-cells with dark blue granules, $\mathrm{B}_{2}$-cells with light blue granules and C-cells without granules (modified aldehyde thionine-hematoxylin-phloxin B).

Electron microscopy indicates that the A-cells of the snake islets contain both small dense and large, less dense granules. B-cells are divided into two types, one of which contains dense spherical granules whereas the other, less dense crystalline ones. Some crystalline granules show a hexagonal shape and a lamellar structure with a periodicity of about $90 \AA$.

The yellow-tail islets contain five different cell types; $A, B_{1}, B_{2}, C_{1}$ and $C_{2}$ cells. The A-cells contain dense spherical granules. The $B_{1}$-cells possess dense crystal granules, some of which are hexagonal in shape like the B-cell granules of the snake. The $\mathrm{B}_{2}$-cells contain less dense amorphous granules. The $\mathrm{C}_{1}$-cells usually show empty vacuoles, whereas the $\mathrm{C}_{2}$-cells contain no secretory granules. Transitional cells occur between $B_{1}, B_{2}$ and $C_{1}$ cells and between $A$ and $C_{2}$ cells, suggesting that they represent functionally different states of the $B$ and $A$ cells rather than different cell types.

The eruptocrine or Type IV extrusion of crystalline granules of the yellow-tail B-cells was clearly shown.

Acknowledgements. The authors wish to thank Prof. Kazumasa Kurosumi, Department of Morphology, Institute of Endocrinology of Gunma University for his kind encouragement and suggestions throughout this work. They are also indebted to the technical assistance of Mrs. Michiko SAto of the same department who very kindly aided in the procurement of specimens.

“隣接切片対応法”による下等脊椎動物の膵臓ランゲルハンス島の研究

(内容自抄)

アオダイショウ (Elaphe climacophora) とブリ (Seriola quinqueradiata) の膵藏ラン ゲルハンス島を光学ならびに電子顕微鏡で観察した. エポン包埋組織を薄切して電子顕 微鏡で観察し，その直後の切片を厚切してアルデヒドチオニンーへマトキシリンーフャキ シン Bで染色し, 光学顕微鏡で観察した. この方法によれば, 同一細胞の電子顕微鏡像 と光学顕微鏡像を対比できる. その結果 次の所見が得られた.

1. ヘビの脺島の $\mathrm{A}$ 細胞の分泌顆粒は光顕では赤染するが，電顕で見ると，暗調の小 さい顆粒とより明調の大きい顆粒とが混在する. B 細胞の分泌顆粒は光顕では青染する が, 電顕では暗調の球形顆粒をもつ細胞と，より明調の結晶状顆粒をもつ細胞とが見ら れる、顆粒はしばしば 6 角形をなし，内部に約 $90 \AA$ の周期性構造を認める。

2. ブリの脺島には A， B，C細胞が存在する. A 細胞は光顕では赤染顆粒をもち， これは電顕では暗調の球形顆粒である. $\mathrm{B}$ 細胞は 2 種類に細分されるが, $\mathrm{B}_{1}$ 細胞の顆粒 は光顕では濃青色を呈し，電顕では結晶性を示し，時に 6 角結晶状をなす， $\mathrm{B}_{2}$ 細胞の顆 
粒は光顕では淡青色を呈し，電顕では明調の球形ないし不整形を呈するが，少数の顆粒 は針状結晶を含む. C 細胞は光顕で分泌顆粒を認めえない細胞で，電顕で 2 型に細分さ れる. $\mathrm{C}_{1}$ 細胞は多数の空胞をもち， $\mathrm{C}_{2}$ 細胞は粗面小胞体の発達した やや暗調な細胞で ある.

3. ブリ脺島の $\mathrm{B}_{1}, \mathrm{~B}_{2}, \mathrm{C}_{1}$ 細胞の間には 移行型が認められるので, これらの細胞は $\mathrm{B}$ 細胞の異なる機能を示すものと思われる. $\mathrm{C}_{2}$ 細胞も $\mathrm{A}$ 細胞との間に移行があり， $\mathrm{A}$ 細 胞の脱顆粒した細胞と思われる.

4. B 細胞の顆粒放出様式は一般にV 型方式と考光られて来たが, ブリの膵島で 結晶 顆粒の IV 型放出も明示された.

\section{References}

Bencosme, S A., J. Meyer, B. J. Bergman and A. Martinez-Palomo: The principal islet of bullhead fish (Ictalurus nebulosus). A correlative light and electron microscopic study of islet cells and of their secretory granules isolated by centrifugation. Rev. Can. Biol. 24: 141-154 (1965).

Björkman, N., C. S. Hellerström., B. Hellman and U. Rothman: Ultrastructure and enzyme histochemistry of the pancreatic islets in the horse. Z. Zellforsch. 59: 535-554 (1963).

Caulfield, J. B.: Effects of varying the vehicle for $\mathrm{OsO}_{4}$ in tissue fixation. J. biophys, biochem. Cytol. 3: 827-830 (1957).

Epple, A.: Weitere Untersuchungen über ein drittes Pankreashormon. Verh. Deut. Zool. Ges. 1965. Ergänz. z. Zool. Anz. 29: 459-470 (1966).

Esterhuizen, A. C. and J. D. Lever: Pancreatic islet cells in the normal and $\mathrm{CoCl}_{2}$-treated guinea pig. A fine structural study. J. Endocrinol. 23: 243-252 (1961).

Falkmer, S. and R. Olsson: Ultrastructure of the pancreatic islet tissue of normal and alloxan treated Cottus scorpius. Acta endocrinol. 39: 32-46 (1962).

Fujita, $\mathbf{H}$. and $\mathbf{Z}$. Matsuno: Some observations on the fine structure of the pancreatic islet of rabbits, with special reference to $B$ cell alteration in the hypoglycemic state induced by alloxan treatment. Arch. histol. jap. 28: 383-398 (1967).

Fujita, T.: D cell, the third endocrine element of the pancreatic islet. Arch. histol. jap. 29: 1-40 (1968).

Gomez-Acebo, J., R. Parrilla and J. L. R-Candela: Fine structure of the A and D cells of the rabbit endocrine pancreas in vivo and incubated in vitro. I. Mechanism of secretion of A cells. J. Cell Biol. 36: 33-44 (1968).

Gomori, G.: Observations with differential stains on human islets of Langerhans. Amer. J. Pathol. 17: 395-406 (1941).

Greider, M. H., S. L. Howell and P. E. Lacy: Isolation and properties of secretory granules from rat islets of Langerhans. II. Ultrastructure of the beta granule. J. Cell Biol. 41: 162-166 (1969).

Herman, L., T. Sato and P. J. Fitzgerald: The pancreas. In: Electron Microscopic Anatomy. New York, Academic Press, 1964 (Chapter 3, p. 59-95).

Ito, T., N. Watari und T. Yamamoto: Studien über Langerhansschen Insel des Pankreas bei der Schlange, Elaphe quadrivirgata. Arch. histol. jap. 20: 311-333 (1960).

Kohama, M.: Electron microscopic studies on the mechanism of insulin secretion from pancreatic $\beta$-cells. Med. J. Osaka Univ. 19: 81-94 (1968).

Kurosumi, K.: Electron microscopic analysis of the secretion mechanism. Int. Rev. Cytol. 11: 1-124 (1961).

Lacy, P. E.: Electron microscopic identification of different cell types in the islets of Langerhans of the guinea pig, rat, rabbit and dog. Anat. Rec. 128: 255-267 (1957a). 
: Electron microscopy of the normal islets of Langerhans. Studies in the dog, rabbit, guinea pig and rat. Diabetes 6: 498-507 (1957b).

-: Electron microscopy of the islets of Langerhans. Diabetes 11: 509-513 (1962).

Legg, P. G.: The fine structure and innervation of the beta and delta cells in the islet of Langerhans of the cat. Z. Zellforsch. 80: 307-321 (1967).

Lever, J. D., M. K. Jeacock and F. G. Young: The production and cure of meta-hypophyseal diabetes in the cat: a biochemical and electron microscopical study with paticular reference to the changes in the islets of Langerhans of the pancreas. Proc. Roy. Soc. (London), Ser. B 154: 139-150 (1961).

Luft, J. H.: Improvements in epoxy resin embedding methods. J. biophys. biochem. Cytol. 9: 409414 (1961).

Machino, M.: Electron microscope observations of pancreatic islet cells of the early chick embryo. Nature 210: 853-854 (1966).

Machino, M., T.Onoe and H. Sakuma: Electron microscopic observations on the islet alpha cells of the domestic fowl pancreas. J. Electron Microsc. 15: 249-256 (1966).

Munger, B. L.: Staining methods applicable to sections of osmium-fixed tissue for light microscopy. J. biophys. biochem. Cytol. 11: 502-506 (1961).

Przybylski, R. J.: Cytodifferentiation of the chick pancreas. I. Ultrastructure of the islet cells and the initiation of granule formation. Gen. comp. Endocrinol. 8: 115-128 (1967).

Reynolds, E. S.: The use of lead citrate at high $\mathrm{pH}$ as an electron opaque stain in electron microscopy. J. Cell Biol. 17: 208-212 (1957).

Sato, T., L. Herman and $\mathbf{P}$. J. Fitzgerald: The comparative ultrastructure of the pancreatic islet of Langerhans. Gen. comp. Endocrinol. 7: 132-157 (1966).

Tarui, S.: Effects of insulin on metabolism. Clin. Endocrinol 14: 27-30 (1966).

Thiery, J. P. et J. B. Bader: Ultrastructure des îlots de Langerhans du pancréas humain normal et pathologique. Ann. Endocrinol. (Paris) 27: 625-647 (1966).

Trandaburu, T. and L. Călugăreanu: Light and electron microscopic investigation of the endocrine pancreas of the grass-snake [Natrix n. natrix (L)]. Z. Zellforsch. 97: 212-225 (1969).

Watari, N.: Fine structure of nervous elements in the pancreas of some vertebrates. Z. Zellforsch. 85: 291-314 (1968a).

- : Ultrastructure of the pancreatic islets under some experimental conditions, with special reference to the morphological changes of B-cells. Fol. endocrinol. jap. 44: 721-727 (1968b).

Watari, N. and L. Herman: Correlative light and electron microscopy of bat islets of Langerhans in hibernating and nonhibernating states. Amer. Zool. 5: 240 (1965).

Watson, M. L.: Staining of tissue sections for electron microscopy with heavy metals. J. biophys. biochem. Cytol. 4: 475-478 (1958).

Williams, R. H. and J. W. Ensinck: Secretion, fates and actions of insulin and related products. Diabetes 15: 623-654 (1966). 